Kohl: a Journal for Body and Gender Research

Vol. 2, No. 2 (Winter 2016)

\title{
Women Revolt: Between Media Resistance and the Reinforcement of Oppressive Gender Structures
}

Shahd Abusalama

\begin{abstract}
:
After a video accidently caught a sexual harassment incident I was subjected to at the Rafah border, my body became the ground upon which the most hegemonic ideological powers operating in Gaza fought for dominance. The video pushed me and my personhood to the margins under the rubric of my "protection" as a woman, an issue that is perceived by the general community as "common sense." The media discourse that surrounded the incident demonstrates women's multiple struggles in the Palestinian community and the central role that media and power structures play in defining and reinforcing certain hegemonic discourses, such as patriarchy. However, women have performed uncountable examples of implicit and explicit resistance to reclaim their agency in the face of oppression and patriarchy. In my case, social media tools allowed me to reclaim the original context of the event and expose the patriarchal cultural traditions that reduces women to their bodies and restricts and marginalises them. It also succeeded in paving the ground for more open discussion around the violations the women are subjected to on a daily basis in public and private spheres, and challenged the cultural taboo around sexual violence against women.
\end{abstract}


At the end of the summer of 2013, the Gaza Strip, widely described as "the world's open-air prison," was enduring a deteriorating political and humanitarian crisis as a result of the continuous closure of the GazaEgypt Rafah Border Crossing. This gate resembles a lifeline for Gaza's population, being their only exit to the outside world. During that time, I was among thousands of people stranded behind Rafah border gate, trying to seek education or work opportunity, or receive medical care abroad. On that day, I was impatiently waiting at Rafah border for my name to be called and be set out when the border was announced to be closed by the Egyptian side. Subsequently, people's accumulative frustration and anger exploded, forming a spontaneous protest against the dehumanising situation they have endured over months of failed attempts to cross the border.

In this essay, I will reflect on a personal experience at this protest that became a story that dominated the local news discourse in Palestine. The story revolves around a video, accidently caught on camera, of me being sexually assaulted by a young man while being at the front line of the protest at the Rafah border gate. The ensuing discourse surrounding the video was manipulated and exploited in a manner that turned the body of the harassed woman into a battleground upon which the competing hegemonic political factions - Hamas and Fatah - fought.

The manipulative and divisive way in which news narratives of the event were framed not only revealed the disturbing political division within Palestinian factions and leadership, but also reinforced oppressive gender structure and norms within the Palestinian society. The strategic misuse of such a video in local news narratives is not only indicative of women's position within Palestinian society, but also of women's multiple struggles within such divided anti-colonial, patriarchal, and nationalistic projects. This, I argue, is a result of the representation of women as the symbol of nation and family's honour, which men live and die for.

In my incident, the woman's picture in the video was pixilated, effectively erasing the woman taking the resulting political debate out of context. This erasure was subtly dictated by the dominant, inherently patriarchal culture within Palestinian societies that presumes publishing a video where a woman is sexually assaulted would bring her shame. However, alternative media tools, such as social media platforms, offer a site of resistance that can be helpful in exposing certain cultural and/or social practices that become "common sense" (Gramsci, 1999, p. 641). Social media tools enabled me to challenge the manipulative media discourse around the incident and reinstate the centrality of the main issue that was marginalised: that sexual assault against women, as well as the taboo constructed around it, is enabled by a patriarchal structure.

With reference to authors such as Deniz Kandiyoti, Nira Yuval-Davis, and Pierre Bourdieu, I argue that patriarchy is not autonomous. It is, rather, diffused within every social sphere, and in both public and in private domains. I use Gramsci's concept of hegemony to understand the hegemonic nature of patriarchy under which such an "extraordinarily ordinary social relation" is naturalised, even to the dominated women (Bourdieu, 2001, pp. 1-3), and explain how it could be established, reinforced, and accepted by "spontaneous consent" (Gramsci, 1999, p. 145).

Finally, through reflecting on my personal story, I argue that the normalisation of the hegemonic power structures that women face does not necessarily mean that women are merely passive subjects who 
simply submit to oppression. Instead, women always face these multiple layers of oppression with different forms of resistance through which they negotiate and enact their own agency and challenge these structures. This is not only limited to Palestinian societies but to most struggles that are grounded in nationalism and anti-colonialism.

\section{Stranded at the Border Crossing}

The Gaza Strip has acquired a metaphor as "the world's biggest open-air prison," due to a ghettoization process that Gaza underwent under the Israeli Occupation. This systematic process did not start with the collaboration between Israel, Egypt, and the International community in imposing a blockade on Gaza after Hamas took control over Gaza, but has been going for decades. According to the Israeli Historian Ilan Pappe, Gaza "was already encircled with an electric fence in 1994 as part of the preparation for peace with the Palestinians and became a ghetto in 2000 when the peace process was declared dead" (Pappé, 2010, p. 192). Following Hamas takeover in 2007, Israel, supported by Egypt and the international community, found an opportunity to tighten the stranglehold on the people of Gaza by imposing an illegal siege defined by most international human rights organisations as a measure of "collective punishment" (Chomsky \& Pappe, 2010). This effectively meant that 1.8 million Palestinians were left locked in the ghetto of Gaza where basic rights are denied, including free access to the rest of the Occupied Palestinian territories and the outside world.

On the 29th of September 2013, I was one of over five thousand people, desperate to leave, who were held at the Rafah border crossing, the only exit to the outside world for the vast majority of Gaza's 1.8 million residents since the blockade was officially imposed in 2007. Following the July 2013 military coup in Egypt that deposed the elected President, Mohammed Morsi, Palestinians' movement across Rafah crossing was further severely restricted. Thousands of registered travellers were stuck in limbo for months, the majority being humanitarian cases, such as patients in need of medical operations, or students trying to continue their studies abroad, or workers whose work permits were due to expire. Regarding my personal circumstances, the closure of Rafah border prevented me from catching my flight from Cairo to Istanbul on September $15^{\text {th }}$, which would have enabled me to undertake my MA scholarship in Turkey.

Around midday, as my fellow hopeful travellers and I were waiting under the sun to hear our names called out, the Palestinian administration of Rafah border crossing made an announcement on loudspeakers. The Egyptian administration had notified the Palestinian administrators that the crossing would be closed until further notice, and we were subsequently asked to return to our homes and keep checking for more information. In response, people's frustration and anger exploded. Students - whose dreams were about to shatter at the threshold of Rafah crossing - were the majority of those who spontaneously started marching towards Rafah gate, protesting for their basic right to travel and catch up with their studies abroad.

I was among the few women who were leading the protest. I was both psychologically and physically exhausted from repeating the same routine daily over the course of almost a month: travelling with my luggage shortly after sunrise from the very north of the Gaza Strip where I live, to the very south of the 
Strip where the Rafah border is located, only to end up dragging it all back home with fading hope at around sunset. At the gate, while chanting for our right to travel and pursue our education, several local and international channels were increasingly amassing to report the crisis at Rafah border. Protesters were packed together, trying to push past the Hamas-authorities-police-guarded gate and break through it, and the police was retaliating. Finally, we broke through the gate and collectively ran in the direction of Egypt with a brief sense of liberation that faded away soon after we encountered police trucks blocking the way. Media then was covering the events.

While standing at the frontline of the protest, between the police and the rest of the mostly-male protesters, a young man standing behind me groped me from behind. My reaction was initially hesitant, as the space was overcrowded with people, and I assumed that someone had simply poked me unintentionally. Shortly afterwards, I realised that the groping was intentional sexual harassment, as the man repeated the same action more aggressively. I turned around and belligerently pushed the harasser in self-defence. A policeman standing in front of me noticed the incident, physically attacked the perpetrator, and arrested him.

I returned home afterwards, feeling violated in every possible sense: as a human being deprived of one of the most basic human rights - that of movement, and as a woman whose self was reduced to a body, a sexual object. After a short nap, I woke up and immediately went to check the official Facebook page of Rafah border to get the latest news about the situation in Rafah, hoping to see my name among the list of travellers for the next day.

The first post that appeared on my Facebook newsfeed was a Youtube video ${ }^{1}$ that was being described as a sexual harassment incident at Rafah border. By the time I watched it, the video was now being widely circulated on different social media networks and received tens of thousands of views. The video was also republished on several local media outlets.

\section{Crossing the Borders of Manipulation and Hegemony}

Palestine Now, a Hamas-affiliated website, published this video under a news report labelled "The truth behind the "sexual harassment" incident at Rafah,"2 and the YouTube video, uploaded in slow motion, was titled "A Fatah-Affiliated member tries to cause a brawl at Rafah border by harassing a young woman and the policeman teaches him a lesson."3 According to Hamas-affiliated news sites, this slow-motion video was allegedly a response to accusations raised by Fatah-affiliated media. Fatah media presented a still photo that captured a policeman hitting a young man, claiming that Hamas authorities had treated the trapped travellers aggressively. Speechless, I sat in front of my computer screen, watching how my body had become the site upon which the competing hegemonic political powers of Hamas and Fatah fought for dominance.

\footnotetext{
${ }^{1}$ YouTube video recording the sexual harassment incident: $h$ ttps://www.youtube.com/watch?v=1eExF-n7MJM

2 Palestine Now was the first Hamas-affiliated website to report the sexual harassment incident:

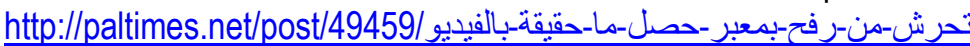

${ }^{3} \mathrm{~A}$ YouTube link to the video that recorded the incident: https://www.youtube.com/watch?v=1nWwShzC3lc
} 
The question here is: what does such a manipulative articulation of the incident reflect about Palestinian politics and the gender structure in Palestinian society?

The video cannot be understood in isolation from the wider context in which the recorded incident occurred. Since the signing of the Oslo Accords, the so-called peace process agreement that the late Edward Said termed "an instrument for Palestinian surrender, a Palestinian Versailles" (Said, 1993), domestic Palestinian politics have largely been defined by competition over political power between Hamas and Fatah. The Islamic Resistance Movement, Hamas, became a governing power after winning the 2006 Palestinian Legislative Council (PLC) elections, an event that its rival Fatah, which had dominated Palestinian politics since 1969, found hard to accept. The political conflict escalated in June 2007 into an outright rivalry that marked the split of the Palestinian occupied territories into a Hamascontrolled Gaza Strip and a Fatah-dominated West Bank (Hroub, 2006) (Løvlie, 2013).

This rivalry between the two political parties was evident in the way news narratives framed the sexual harassment incident, an articulation that benefited Hamas politically through what Jennifer Daryl Slack describes as "a way of foregrounding the structure and play of power that entail in relations of dominance and subordination" (Slack, 1996). For political ends, Hamas reconstructed the narrative of the event using media tools, partisan language, and culture codes, or what people perceive as the collective "common sense," to make it relatable to the audience, and effectively reinforce its hegemonic status as the dominant political power in the Gaza Strip.

Hegemony appears as the "common sense" that guides our everyday, and is naturalised within the society as the mundane understanding of the world. It is a view of the world that is "inherited from the past and uncritically absorbed" and tends to reproduce a sort of "social homeostasis," or "moral and political passivity" (Gramsci, 1999, p. 641). This case can serve as a good example of how "common sense" is an articulation of hegemonic social structures. In the video that Hamas-affiliated news sites circulated, the woman's image - mine - was pixelated to allegedly protect her or to avoid causing her any scandal. Since she was refused an image, she had no name and no voice.

In addition, the power relations embedded in this representation of the incident were evident, not only in the portrayal of the woman as a subordinate subject without agency, but also in the audience response. It mostly marginalised the sexual assault and focused on commending the Hamas policeman's "protective" response. Instead, the news narrative redirected the public attention to other irrelevant details that were made significant, such as the political affiliation of the policeman and the harasser. Hamas' appropriation of the incident to reaffirm its self-image was met with almost no critical response, except for a few that did so based on the association of the harasser with his political affiliation, Fatah. When it comes to me, I was pushed to the margins of both the sexual assault incident that I was a victim of and the political discourse that surrounded it. I had no say over the exploitative way in which such a traumatic experience was used politically by the two rivals - Fatah and Hamas.

Deniz Kandiyoti points out that in nationalist projects of patriarchal nature, such as the Palestinian anticolonial struggle, women tend to be socially and politically marginalised despite the relentless assertions of their centrality to the nation, a reaffirmation that is made either conscious or unconsciously (Kandiyoti, 1991). Women's centrality is "reaffirmed consciously in nationalistic rhetoric where the nation itself is 
represented as a woman to be protected or, less consciously, in an intense preoccupation with the women's appropriate sexual conduct" (Kandiyoti, 1991). However, Palestinian women have always engaged with day-to-day resistance, whether implicitly or explicitly, against both the Israeli oppression and existing patriarchal structures that are deeply rooted within the national liberation movement.

In this case, women were at the frontline of a demonstration that symbolised a form of resistance to a suppressive situation in which basic rights are denied, and were doing so with Hamas' approval. However, when political parties intervened, Fatah appropriated the incident at Rafah border in a way that shook Hamas' self-image. Hamas, in turn, responded by publishing the slow-motion video to justify Hamas police's violence and solidify its hegemonic status. The easy dismissal of the woman from the political discourse was uncritically perceived as the "norm" or "common sense;" it comes under the rhetoric that women, like the nation, need to be protected as presumably, the exposure of her identity would harm her reputation. This protective attitude towards women and their "reputation" indicates the burden that women endure by being tasked with representing and upholding the honour of both men and the nation.

When I first saw this video becoming viral on social media networks, the trauma that I had suffered from that sexual assault, on top of the collective misery I witnessed first-hand at Rafah border during my multiple failed attempts to cross it, felt doubled. I was sickened by the appropriation of the incident by Hamas to affirm its hegemonic status as a political power, and by the uncritical public response that reflected the hegemonic gendered regime in which patriarchy dominates. I felt that my body was an instrument of borders, whether physical or political, trapped by intersecting systems of oppression.

\section{Reclaiming Narrative through Social Media Platforms}

Both parties resorted to using online media in order to construct and solidify their political stands on the incident. It was hard to sit back and watch this political manipulation of the sexual assault and the public's uncritical interaction prevailing on local news sites and social media platforms. Though it was a personal experience, I was the subject of this assault, not because of who I was, but because of my gender. Therefore, any woman could have been in my place. This example is a manifestation of how, in the context of Palestine, the personal, the collective, and the political always intersect. Having that in mind, I also resorted to social media tools, which offered me a space to resist the manipulative narratives and a platform to reconstruct and situate the event in its original context.

In a Facebook post, I revealed my identity hoping that the main issue would reclaim its centrality, and that women would feel empowered to raise their voices against any violation they are subjected to by men. I publicly rejected the instrumentalisation of my body to sustain the political conflict between Fatah and Hamas. I emphasized the influence of the cultural traditions that reinforce patriarchy and enable such violations against women to continue without even being critiqued. Finally, I asked for the video to be circulated as widely as possible in an attempt to challenge the suppressing nature of the patriarchal society that tends to promote silence, restrict women, and blame them even when they are the subject of oppression. 
The video was among the first of its kind to be publically displayed; it showed the challenges that women endure in the public domain of this particular "gender regime," where gender relations are shaped by inequality and hegemonic masculinity. The video, therefore, provided an opportunity to pave the ground for issues deemed taboo by society, such as sexual harassment and domestic violence. In addition, it allowed for the creation of a dialogue on these issues, as they were tackled in the public sphere in a bid to raise awareness among the population. Local and international media platforms republished my post within its original context, such as Al-Quds Al-Arabi Magazine, ${ }^{4}$ Sawt Al-Watan website, ${ }^{5}$ and France 24 TV. ${ }^{6}$ However, the reactions to my Facebook post revealed conflicting opinions.

On the one hand, I was subjected to many hostile comments by a number of actors, ranging from Hamas officials, to neighbours and extended family, to strangers online, who viewed my stance as inappropriate. A popular proverb that has been passed from one generation to another claims that "woman's reputation is like a glass; once broken, it cannot be repaired." This is only one example of a cultural code that shapes the way in which the public react to issues, such as sexual violence against women, a code that enables the culture of suppression around them. The vast majority of opponents were shocked that I refused to conform to the hegemonic culture that would expect women to sit silent after being sexually violated because otherwise, it would presumably dishonour not only the woman, but also her family. Both opponents and supporters did not understand how, despite the wide publicity that the video received they presumed that this would have a deterrent effect on me, I still disclosed my identity, stating, "I will not be ashamed to reveal that I was the victim of this sexual assault."

Many people, including women, blamed me for not being "covered" enough in a public space where direct interaction with men is inevitable, a setting that arguably arouses men's sexual instinct "naturally;" others denied that such occurrences are rampant in our society and claimed that revealing my identity was a "rude attempt to seek fame." These women and the "common sense" they claimed to be citing exemplify the internalization of patriarchy by those who are more vulnerable to its hegemonic dimensions. As a hegemonic discourse, patriarchy functions in a way that makes such an "extraordinarily ordinary social relation" appear naturalised and become internalised as "the common sense," even to the subordinate women (Bourdieu, 2001, pp. 1-3) (Gramsci, 1999, p. 641).

To better understand the public reaction to me disclosing my identity, we need to remember that patriarchy is not an autonomous social system. It is rather embedded in every social sphere, whether private or public (Yuval-Davis, 1997, p. 7). As Suad Joseph suggests, "the boundaries between this triangulation of state, civil society, and kinship or private domain are highly fluid. People's commitments remain grounded in kin and community, and they carry those commitments with them, whether in the civil or state spheres" (Joseph, 1993, pp. 22-26). In my case, the attitudes of both the Hamas policeman towards the harasser and the video editor who blurred my picture were based on these cultural moralities that are fostered in the privacy of the home and implemented in their public positions. Similarly, men in position of power, such as the General Administrator of Rafah Border Maher Abu Sabha, acted based on this cultural influence. Abu Sabha met me the day after my story gained momentum and claimed to be

\footnotetext{
${ }^{4}$ Al-Quds Al-Arabi's report: http://www.alquds.co.uk/?p=89333

${ }^{5}$ Sawt Al-Watan report: http://www.alwatanvoice.com/arabic/news/2013/09/30/441728.html

${ }^{6}$ France 24 video: https://www.youtube.com/watch?v=dKIh6CGva3w
} 
advising me "as a father." He told me: "if you were more modest, you would have avoided being harassed."

Hegemony, according to Antonio Gramsci, is not simply a pattern of domination based on force. Although hegemony could be supported by force, it is historically achieved through culture, institutions, and persuasion. It is induced through "the spontaneous consent" of the masses, which "the dominant group enjoys because of its position and function in the world of production" (Gramsci, 1999, p. 145). The civil society's institutions - religion, schools, family, and mass media - are largely responsible for enacting and reproducing such a gendered and racist power structure. In my case, media was heavily manipulated to reinforce these existing hegemonic discourses.

As a form of power, hegemonic discourses are always met with resistance in one way or another (Foucault, 1982). So, contrary to the hegemonic nature of patriarchy, women should not be perceived as passive subjects who simply submit to how the male determines gender relations. Women have been resisting or bargaining with patriarchy for centuries (Kandiyoti, 1988). There have always been women's movements that call for equal political, economic, cultural, and social rights for women. Currently, media has been increasingly used as a site of resistance and self-expression for many feminist groups worldwide.

Revealing my identity sparked a movement that perceived my story as an opportunity to take the streets, resist, speak publicly about sexual harassment against women, and demand gender equality and justice for victims of sexual violence. Many women felt empowered to disclose their personal experiences of being subject to sexual assaults. The movement was substantial enough to put local news under pressure

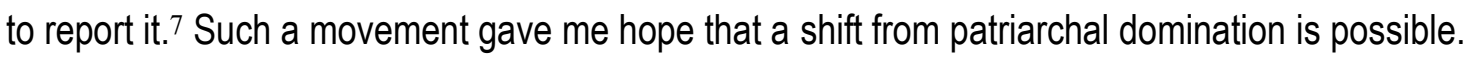

Palestinian women have been facing multiple layers of oppression, whether from the Israeli occupation, the dominant patriarchal culture, or the male-dominated leading political powers, most importantly the PA government in the West Bank and Hamas in the Gaza Strip. Despite this, women have played a central role at the forefront of the national struggle, which has existed ever since the emergence of the Palestinian cause towards the end of the nineteenth century when the first Zionist colonies were built. There are numerous examples of Palestinian women who were engaged in active resistance against the British Mandate and Zionism, such as the armed women's organisation Zahrat Al-Uqhawan, originally founded as a social organisation in 1933 in Yafa by the two sisters Moheba and Arabiya Khursheed. They adopted armed struggle against British Colonialism after Moheba witnessed a British sniper shooting dead a child while in his mother's arms (Alsaafin, 2014). Palestinian women, as in other nationalist struggles, have used moments of political instability and collective resistance to negotiate with the existing gender norms. Even if they did not have an explicit feminist agenda, they were able to perform an indigenous form of feminism that appealed to their own specific cultural and social settings (Fleischmann, 2000) (Kandiyoti, 1991). The political instability at the Gaza-Egypt Rafah border served as an opportunity for the competing political factions, Hamas and Fatah, to exploit the sexual assault incident, which happened in the middle

\footnotetext{
${ }^{7}$ An article published by a widely-read Palestine-based website AI-Watan Voice titled: Is it a one-off incident or a phenomenon? Young Women thank the victim of Rafah Border's sexual assault for her bravery and call on police to punish all harassers: https://www.alwatanvoice.com/arabic/news/2013/09/30/441959.html
} 
of a women-led, male-dominated protest, for their political ends. This created further instability and paved the ground for me to disclose my identity, resist the manipulative discourse in which my sexual assault was situated, place it in its original context, effectively exposing the existing oppressive gender regime and evoking women's mobilisation against sexual violence.

Despite this persistent assertion of agency, women are still perceived as subordinate, as something to be "protected" or a motive for men to "live and die for" (Yuval-Davis, 1997, p. 45). Palestinian political parties, regardless of their ideological affiliation, whether they be secular, Marxist, or Islamist, have been reproducing gender norms to a large extent. The perception of women as the fertile "womb" whose role is limited to reproducing the nation is shared among most nationalist projects (Jad, 2011, p. 180). Moreover, women are "the bearers of the 'burden of representation' whose bodies embody the nation's collective identity, honour and future destiny" (Yuval-Davis, 1997, pp. 45-47). In Palestine, women have been trapped between these different ideologies that used similar gender discourses by relying on the general "culture" of the region. For instance, Ahmad Yassin, the founder of Hamas, once suggested that women should be "the second defence line" and that their role should be limited to the private sphere as reproducers of the nation, and bearers of the grief and sorrow resulted from the loss of their male relatives (Hasso, 2005, p. 31). Palestinian women, however, persistently resisted this normative role which confined them to their supportive relationship to a man.

There are multiple examples of Palestinian women who participated in active resistance, including armed struggle against the Israeli colonial project, and effectively challenged the "protected-protector" myth, such as Dareen Abu Aisheh, Dalal Mughrabi and Shadia Abu Ghazalah (Yuval-Davis, 1997, p. 111) (Hasso, 2005, pp. 23-51). It is important, however, to acknowledge that women in Palestine have historically suffered as well as resisted, not only on a political level, but also on a social level. It is equally important to shed the light on the shortcomings of the vast majority of women's organisations in Palestine, especially those affiliated with political parties, as they work within the parameters of women's issues being secondary to the nationalistic struggle to liberation. I am convinced that national liberation can never be accomplished within a patriarchal structure, and that women's emancipation must go hand in hand with the process of liberation and resistance, not afterwards.

\section{Conclusion}

The sexual harassment incident I was subjected to offers an example of the multiple struggles that Palestinian women face; they are confronted with oppressive political situations under the Israeli, Egyptian, and internationally-backed blockade on Gaza, combined with the fragmented and divided political leadership, and the oppressive gender structures that dominate both the public and private spheres. As I was stranded at Gaza's Rafah border, protesting with other stranded Palestinian travellers against the denial of our basic right to free movement, my imprisoned body was the subject of a sexual assault by a member of the public. The beneficiary rival political powers - Fatah and Hamas manipulated the sexual assault, reducing my body to a site onto which they both fought for power. This left me violated in every possible sense, trapped at the borders of intersecting oppressive power systems. 
Just as I was powerless behind the Rafah border that shut its gate in the face of tens of thousands of travellers, I had no say over neither the harasser's abusive actions, nor the online dissemination of the video that accidently recorded the sexual assault, nor the manipulative narrative around it. However, demonstrating at Rafah border against its closure was an act of resistance. Defending myself against the harasser, who assumed the surrounding crowd of protesters would make me a vulnerable prey, was an act of resistance. Disclosing my identity, despite the wide publicity that the recording of the sexual assault received, was an act of resistance. Speaking up through social media tools empowered me and made me able to engage with the ensuing political debate, place the sexual assault in its original context, expose Hamas and Fatah's manipulative actions, and make a change.

Sexual violence against women as a form of oppression enabled by hegemonic patriarchal structures became the centre of debate, despite the victim-playing arguments by its uncritical hostages. Speaking up also exposed how the two political rivals Fatah and Hamas manipulated the sexual assault, effectively highlighting the division that separates the Palestinian leadership from its societies and diverting the attention from the collective misery that Palestinians endured under Gaza's ghetto. Speaking up caused a substantive media uproar that encouraged debate around issues that are considered taboo within Palestinian society, and brought the attention back to the humanitarian crisis that Gaza's population endured because of the closure of the Rafah border. High political figures in the Hamas Government directly contacted me the day after I spoke up, setting me free out of Rafah border. While I was able to cross that geopolitical border, others remain to be navigated. 


\section{References}

Al-Ali, N. S., 2002. Women's Movements in the Middle East:Case Studies of Egypt and Turkey. Available at: http://eprints.soas.ac.uk/4889/2/UNRISD_Report_final.pdf [Accessed 1012015 ].

Alsaafin, L., 2014. The role of Palestinian women in resistance. Available at: https://www.opendemocracy.net/arab-awakening/linah-alsaafin/role-of-palestinian-women-inresistance [Accessed 2311 2016].

Bourdieu, B., 2001. Masculine Domination. s.l.:Polity Press.

Chomsky, N. \& Pappe, I., 2010. Gaza in Crisis: Reflections on the US-Israeli War on the Palestinians. Chicago: Haymarket Books.

Filiu, J.-P., 2014. The Twelve Wars on Gaza. 44(1).

Fleischmann, E., 2000. Women's Suffrage in the British Empire: Citizenship, Nation and Race. London: Taylor \& Francis.

Foucault, M., 1982. "The Subject and power." Critical Inquiry, 8(4), pp. 777-795.

Gramsci, A., 1999. Selections from the Prison Notebook. London: ElecBook.

---. 2007. Prison Notebooks. Volume 3, p. 168.

Hasso, F. S., 2005. "Discursive and Political Deployments by/of the 2002 Palestinian Women Suicide Bombers/Martyrs." Feminist Review, Volume 81, pp. 23-51.

Hroub, K., 2006. "A 'New Hamas' through Its New Documents." Journal of Palestine Studies, 35(4), p. 10.

Jad, I., 2011. "Islamist Women of Hamas: Between Feminism and Nationalism." Inter-Asia Cultural Studies, Volume 12, pp. 176-201.

Joseph, S., 1993. "Gender and Civil Society: An Interview with Suad Joseph." Middle East Report, Volume 183, pp. 22-26.

Kandiyoti, D., 1988. "Bargaining with Patriarchy." Gender and Society, 2(3), pp. 274-290.

---. 1991. "Identity and its Discontents: Women and the Nation." Millennium - Journal of International Studies, 20(249).

Katz, Y., 2013. The Role of the Press in the Unilateral Disengagement Plan of Israel from Gaza Strip. Open Journal of Political Science, 3(1).

Korn, A., 2008. "The Ghettoization of the Palestinians." In: R. Lentin, ed. Thinking Palestine. London: Zed Books, pp. 116-130.

Løvlie, F., 2013. "Explaining Hamas's Changing Electoral." Government and Opposition, 48 (04 ), p. 578.

Li, D., 2006. "The Gaza Strip as a Laboratory: Notes in the Wake of Disengagement." Journal of Palestine Studies, $x x x v(2)$, pp. 38-55.

Pappé, I., 2010. The Killing Fields of Gaza, 2004-2009. Chicago: Haymarket Books, pp. 189-211.

Rose, D., 2008. The Gaza Bombshell. Available at: http://www.vanityfair.com/news/2008/04/gaza200804 [Accessed 1509 2015].

Said, E., 1993. The Morning After. London Review of Books.

Slack, J. D., 1996. "The Theory and Method of Articulation in Cultural Studies." In: D. a. K. C. Morley, ed. Stuart Hall: Critical Dialogues in Cultural Studies. s.l.:s.n., p. 113.

Stefano, P. D., 2014. Gaza and the politics of forgetting. Available at: http://rabble.ca/news/2014/07/gazaand-politics-forgetting [Accessed 2008 2015].

Tucker, J., 1993. "Introduction." In: Women: Old Boundaries, New Frontiers. s.I.:Indiana University Press, p. vii. 
Yuval-Davis, N., 1997. Gender \& Nation. London: Sage publication. 